\title{
Valuation of Gender Differentiated Dairy Farming and Household Level Food Security Status in Eastern Oromia, Ethiopia
}

\author{
Beyan Ahmed Yuya* \\ School of Agricultural Economics and Agribusiness, Haramaya University, P.O.box 95 Dire Dawa, Ethiopia
}

\begin{tabular}{l} 
A R T I C L E I N F O \\
Research Article \\
Received 26 December 2017 \\
Accepted 27 February 2018 \\
\hline
\end{tabular}

Keywords:

Gender

Valuation

Dairy farming

Food security

Propensity score matching

*Corresponding Author:

E-mail: beyanhmd@gmail.com

\begin{abstract}
A B S T R A C T
This study was aimed at examining gender diversified dairy farming and household level food security status and determinants of dairy cattle benefits in Haramaya district, Oromia, Ethiopia, using cross sectional data collected from randomly selected 120 sample households during year 2016 production season. Descriptive statistics and multiple linear regression models were employed for data analysis. Descriptive statistics stated that of the sample households, 71 households were found to be food secured whereas the remaining 49 household were food unsecured. Comparison of female headed and male headed dairy farming households indicated that 46.7 percent's of female headed and 12.5 percent's of male headed households were secured. The logistic regression result showed that female headed dairy farming participation was significantly influenced by education of household head, extension contact, cultivated land area, availability of supplementary feeds and access to market information. The impact estimation result showed that female headed have got increment in farm household's food security status nearly by $66 \%$ than male headed households. The regression estimated coefficients indicated that dairy cattle benefits is significantly influenced by; education, access to vaccination, extension service, market information, cultivated area, milk sold on farm and fodder supplement were significant variables which affect the dairy cattle income in the study area. Therefore, policy makers should give due emphasis to the aforementioned variables to increase dairy farming benefits and improve the livelihood of rural households.
\end{abstract}

DOI: https://doi.org/10.24925/turjaf.v6i6.719-728.1772

\section{Introduction}

Ethiopia is known for its crop and livestock diversity that is distributed across different agro-ecologies and socio-cultural settings. The country has the largest livestock population in Africa, with 52 million cattle, 25 million sheep, 21 million goats and 38 million chickens (CSA, 2010). More than $84 \%$ of the total 90million people depend on agriculture for their livelihood. The mixed crop-livestock system, which prevails mostly in the highlands of the country, harbour's more than $60 \%$ of the people and two thirds of the ruminant population (Dejene, 2003; Cecchi et al., 2010). Large areas of the mixed farming systems in Ethiopia experience high population pressure with spatial differences across the country (Regassa and Yusufe, 2009).

Livestock is considered a key asset for rural households worldwide and a primary livelihood. Livestock "widens and sustains three major pathways out of poverty. Especially in rural areas, the development of small-scale livestock enterprises must be seen as a key element of any efforts to eradicate extreme poverty and hunger (FAO 2010; FAO, 2012; ILRI, 2007).

Cattle in the mixed crop-livestock system of Ethiopia play an important role in the provision of products and by-products, which also include services in crop cultivation processes. Crop production in Ethiopia typically uses a pair of oxen, while cows are kept for breeding and milk production. Cow milk is among the ten most important agricultural commodities in the country, and was ranked as primary animal product in terms of quantity produced. The average per capita supply of whole milk and meat were 16 and $8 \mathrm{~kg}$, respectively (FAOSTAT, 2009; FAOSTAT, 2013). Indirectly contribute to food and nutrition security of farming households. Low production levels are caused by various factors including resource availability, genetic potential of animals, livestock management, production objectives of farmers, as well as physical and institutional infrastructures (Ayele et al, 2003; Mekonnen et al., 2012). 
In rural societies, where local culture and traditions are still very vibrant, responsibilities and tasks are often assigned to women and men on the basis of traditional gender roles. These roles change over time, have different characteristics in every local context and are shaped by ideological, religious, cultural, ethnic and economic factors. They are a key determinant of the distribution of resources and responsibilities between men and women. In many cases gender roles are biased and favour certain social constituencies at the expense of others. Rural In fact, despite their major involvement in and contribution to livestock management, women tend to have limited access to resources, extension services and less participation in decision making compared to their male counterparts (FAO, 2010; FAO, 2011).

Rural women perform a reproductive role, encompassing child bearing, child rearing and housework. At the same time, they also fulfil productive roles. In some developing countries, they make on average up to 43 percent of the agricultural labour force and contribute substantially to the livestock management. In particular, activities related to small livestock production, milking and processing of milk, are carried out mainly by women and, to some extent, by children (Okali, 1985; FAO, 2011).

Despite their important contribution and role in livestock management, women often face greater constraints than men in accessing natural resources, extension services, marketing opportunities and financial services as well as in exercising their decision-making powers. Thus, when rural women access and control the livestock or livestock products they own or manage, household coping strategies may be affected, resulting in a positive impact on overall household well-being and, in particular, nutrition (IFAD, 1999; FAO, 2012). Gender disparities can also have negative consequences on women's ability to earn a stable income and have an adverse impact on overall household income earned at the household level from livestock production. (WHO, 2009).

Gender is a critical variable in development process; many studies previously done on gender have indicated that there is lack of gender disaggregated data, especially on women's contribution to smallholder dairy farming. Gender biases persist, as farmers are still generally perceived as 'men' by policy makers, development planners and agricultural service providers. Lack of available gender disaggregated data means that women's contribution to dairy production in particular is poorly understood and that their specific needs are too often ignored in development planning (Esther Jepkenei, 2009).

In addition to its role at farm household level, livestock make an important contribution to the national economy. However, the multidimensional contribution of livestock to farm households and the national economy is often underestimated, mainly due to the absence of adequate information at farm and national levels (Alary et al., 2011). In addition to this there is no significant researched research and information on gender differentiated dairy farming and their contribution to households' food security status in the study area. Therefore, this study was aimed to asses and quantify the contribution of gender differentiated dairy farming to household food security status, and to determine underlying factors that determine gender participation in dairy farming and their benefits.

\section{Material and Method}

\section{Back Ground of the Study Area}

The study was conducted in East Hararghe Zone, Haramaya district Oromia, Ethiopia. The district located at the distance of $508 \mathrm{~km}$ from Addis Ababa and $18 \mathrm{~km}$ from Harar town in the west direction. According to CSA (2015), Haramaya district has a total population 271, 394 of which 138,376 are male and 133, 018 are female. A total area of the district is about $55 \mathrm{~km}^{2}(55,100 \mathrm{ha})$, the total cultivated land is 38,497 ha. The mean annual rainfall is $492 \mathrm{~mm}$ ranging from $118-866 \mathrm{~mm}$, and located at $42^{\circ} 30^{\prime} \mathrm{E}, 9^{\circ} 26^{\prime} \mathrm{N}$. The major crops grown in the area include sorghum, maize, haricot bean, wheat, barley, ground nut, potato, onion and vegetables. The most common cash crops in the district are vegetables. Livestock are important components of the farming system for consumption and source of income. The livestock rearing is mostly not greater than four animals per household because of shortage of grazing land, the animal feeding method is most commonly have experienced the cut and carry system.

Both primary and secondary data sources were used. The primary data were collected using semi-structured a questionnaire administered by trained enumerators. Secondary data were collected from relevant sources such as published and unpublished documents from the agricultural and rural development offices of the district for general description to augment primary data.

The sampling procedure used was two stage random sampling. In the first stage out of the peasant association exist in the district two peasant were randomly selected. In the second stage, every peasant was stratified in to male headed and female headed households. Then sample respondents were selected randomly based on probability proportion to size. Finally, a total of 120 sample respondents were interviewed.

\section{Data Analysis}

The study employed both descriptive statistics and econometric model of data analysis techniques. The multiple regression analysis was used to identify the determinants of dairy income in the study area and propensity score matching used for impact evaluation.

\section{Food Consumption per Adult Equivalent}

The calorie content of food items consumed by sample households were computed using calorie conversion table of Ehnri (1968) and Households members were converted to their adult equivalent. Then, the amount of total calories consumed by each sample Households were computed and divided by 14 days to get per day calorie consumed by a Household, This figure was finally divided by the Adult Equivalent (AE) of respective Households, yielding the amount of calorie consumption per AE for each sampled Households. Then, mean comparisons of calorie consumed per AE were made for male and female headed groups. Experience -based measures are also subject to response bias deriving from unique personal and cultural values, individual responses that may not reflect the opinions of the household and recall bias of food consumption periods (Jones et al., 2013). Perhaps most importantly from a measurement 
perspective, recent research suggests household food consumption expenditure results can vary significantly based on survey design, with some authors arguing this should be only used with great caution until more consistent and comparable survey data collection can be completed (De Weerdt et al., 2014; Carletto et al., 2012).

\section{Propensity score matching (PSM) method}

Propensity score matching (PSM) was used to estimate the impact gender differentiated dairy farming on the household food security status. Thus, the fundamental problem of such an impact evaluation is a missing data problem. In other words, we are interested in answering the research question "what would have been the food security status of female and male headed households' be if female headed not participated in dairy farming was not in place?" Hence, this study applied PSM technique, which is a widely applied impact evaluation instrument in the absence of baseline survey data and randomization.

The average treatment effects are calculated using propensity score matching method. According to (Becker and Caliendo 2007), matching has become a popular method to estimate average treatment effects. The method is based on the conditional independence assumption, which states that the researcher should observe all variables simultaneously influencing the participation decision and outcome variables which are incomes and food security status in this analysis. Income or productions are traditionally used to measure effect of agricultural technology adoption (MoFED, 2012). Prior to estimating the impact of female headed, specifying the propensity scores for treatment variable using logit model is required (Mendola, 2007). Hence the logit model is applied in this case to predict the probability of female dairy farming participation. To identify the impact of the female headed dairy farming on the sample households, in the study, outcome variables which is food security status was analysed using the propensity Score match of the female headed and male headed households. Propensity score matching has the advantage of reducing the dimensionality of matching to a single dimension. This is the best possible procedure to follow since the households in both female headed and male headed samples might have similar or closer propensity scores even though they might be dissimilar on the basis of each covariate (Rubin and Rosenbaum, 1983).

In this study, the impact of female headed dairy farming in east Hararghe is analysed through causal effect of average food security status between female and male headed using propensity score match. This is possible because the impact is calculated by average treatment effect (ATE) or ATT average treatment effect for the treated.

In the case of a binary treatment the treatment indicator $D_{i}$ equals one if individual i receives treatment and zero otherwise. The impact of a treatment for an individual $i$, noted $T i$, is defined as the difference between the potential outcome in case of treatment and the potential outcome in absence of treatment: Following (Rubin and Rosenbaum, 1983) model the evaluation equation stated as below;

$T_{i}=Y_{i}(1)-Y_{i}(0)$
The fundamental evaluation problem arises because only one of the potential outcomes is observed for each individual $i$. The unobserved outcome is called counterfactual outcome. Hence, estimating the individual treatment effect $i$ is not possible and one has to concentrate on (population) average treatment effects.

ATT, which measures the impact of the program on those individuals who participated:

$T^{A T T}=E[(T) D=1]=E[Y(1) \mid D=1]-E[Y(0) \mid D=1]$

The second term - E[Y(0)|D = 1] is not observed, we do observe $\mathrm{E}[\mathrm{Y}(0) \mid \mathrm{D}=0]$ thus we can calculate:

$E[Y(1) / D=1] E[Y(0) / D=0] \exists^{4 T T}+E[Y(0) \mid D=1] E[Y(0) \mid D=0]$

The difference between the left hand side of equation (7) and ATT is the so-called 'self-selection bias'. The true parameter $\mathrm{T}^{A T T}$ is only identified, if:

$E[Y(0) / D=1]-E[Y(0) / D=0]=0$

Regression Analysis

Multiple linear regression model was employed to identify factors affecting dairy cattle benefits. The mathematical specification of the model is as follows:

$Z_{i}=\beta_{0}+\beta_{1} x_{1}+\beta_{2} x_{2} \ldots .+\beta_{n} x_{n}+u_{i}$

Where; $\mathrm{Z}_{i}=$ Amount of income per cow for each sample households. $\beta_{0}, \beta_{1}, \beta_{2}, \ldots, \beta_{n}$ are parameters to be estimated, and $\mathrm{u}_{i}$ is a random disturbance term.

\section{Results and Discussions}

\section{Preliminary Statistical Results}

Continuous variables: According to the study result, the average cultivated land size of the sample households was 0.6 hectare. When we compare the average cultivated land size between female headed and male headed households, the study revealed that male headed households have smaller cultivated land sizes than female headed households. Mean comparison of cultivated land size between the two groups showed that there was a statistically significant mean difference between two groups (Table 1).

According to the study result, the average grazing land size of the sample households was 0.116 hectare. When we compare the average grazing land size between female headed and male headed households, the study revealed that male headed households have smaller grazing land sizes than female headed households. Mean comparison of cultivated land size between the two groups showed that there was a statistically significant mean difference between two groups.

The mean livestock holding in Tropical Livestock Unit (TLU) for the sample households was 5.4. The mean livestock holding for female headed households was 6.3 TLU and 4.4 TLU for male headed households. The mean comparison for the two groups showed that there was statistically significant mean difference between two 
groups in terms of livestock holding at less than 1percent probability level (Table 1).

The mean number of milking cow for the sample households was 3.4. The mean milking cow for female headed households was 3.8 and 2.8 for male headed households. The mean comparison for the two groups showed that there was statistically significant mean difference between two groups in terms of number of milking cow at less than 1percent probability level (Table 1).

The mean milking produced for the sample households was 16.78 litres. The mean milking produced for female headed households was 19.52 and 13.3 for male headed households. The mean comparison for the two groups showed that there was statistically significant mean difference between two groups in terms of milk produced at less than 1 percent probability level.

The mean dairy income of the sample households was 4043.5 birr. The average dairy income for female headed households was 4891.38 birr while the average for male headed households was 2970 .8birr. The mean comparison between the two groups showed that there was statistically significant mean difference between the two groups in terms of dairy income at less than 5 percent probability level (Table 1).

Table 1 Preliminary statistical result for continuous variables

\begin{tabular}{l|cccccccc}
\hline \multirow{2}{*}{\multicolumn{1}{c}{ Variables }} & \multicolumn{2}{c}{$\begin{array}{c}\text { All sample } \\
\text { households }\end{array}$} & \multicolumn{2}{c}{$\begin{array}{c}\text { Female headed } \\
\text { households }\end{array}$} & \multicolumn{2}{c}{$\begin{array}{c}\text { Male headed } \\
\text { households }\end{array}$} & \multicolumn{2}{c}{$\begin{array}{c}\text { Mean } \\
\text { difference }\end{array}$} \\
\cline { 2 - 7 } & Mean & S.E & Mean & S.E & Mean & S.E & \\
\hline Cultivate & 0.62 & 0.09 & 0.70 & 0.07 & 0.52 & 0.05 & 0.15 & $1.816^{* *}$ \\
Grazing & 0.12 & 0.11 & 0.15 & 0.02 & 0.07 & 0.01 & 1.66 & $3.475^{* * *}$ \\
Cow number & 3.40 & 0.15 & 3.80 & 0.19 & 2.77 & 0.21 & -0.79 & $-3.708^{* * *}$ \\
Livestock hold & 5.40 & 0.24 & 6.30 & 0.29 & 4.40 & 0.37 & -0.79 & $-3.979 * * *$ \\
Milk produced & 16.78 & 0.99 & 19.52 & 1.34 & 13.30 & 1.33 & -7.78 & $-3.217 * * *$ \\
Milk income (ETB) & 3930.00 & 242.80 & 4712.80 & 295.60 & 2940.50 & 362.50 & -2336.80 & $-3.857 * * *$ \\
Dairy income (ETB) & 4043.50 & 228.90 & 4891.40 & 2712.00 & 2970.80 & 335.90 & -3327.00 & $4.498^{* * *}$ \\
\hline
\end{tabular}

Source: Own survey result, 2017, ** and *** means statistically significant at 5\% and 1\% respectively, ETB=Ethiopian Birr, $(1 \mathrm{USD}=23.06 \mathrm{ETB}$ on January 25, 2016).

Table 2 Preliminary statistical result for dummy variables

\begin{tabular}{|c|c|c|c|c|c|c|c|c|}
\hline \multirow{2}{*}{\multicolumn{2}{|c|}{ Variable }} & \multicolumn{2}{|c|}{ Female headed } & \multicolumn{2}{|c|}{ Male headed households } & \multicolumn{2}{|c|}{ All sample households } & \multirow{2}{*}{$\begin{array}{l}\mathrm{Chi}^{2} \\
\text { value }\end{array}$} \\
\hline & & Number & $\%$ & Number & $\%$ & Number & $\%$ & \\
\hline \multirow{2}{*}{ Education } & Illiterate & 12 & 10.0 & 27 & 22.5 & 39 & 32.5 & \multirow{2}{*}{$11.807 * * *$} \\
\hline & Literate & 55 & 45.8 & 26 & 21.6 & 81 & 67.5 & \\
\hline \multirow{2}{*}{ Supplement } & No & 22 & 18.3 & 38 & 31.7 & 60 & 50.0 & \multirow[t]{2}{*}{$17.877 * * *$} \\
\hline & Yes & 45 & 37.5 & 15 & 12.5 & 60 & 50.0 & \\
\hline \multirow{2}{*}{ Vaccination } & No & 25 & 20.5 & 30 & 25 & 55 & 45.8 & \multirow[t]{2}{*}{$4.435 * * *$} \\
\hline & Yes & 42 & 35.0 & 23 & 19.2 & 65 & 54.2 & \\
\hline \multirow{2}{*}{ Market info } & No & 6 & 5.0 & 17 & 14.2 & 23 & 19.2 & \multirow[t]{2}{*}{$10.210 * * *$} \\
\hline & Yes & 61 & 50.8 & 36 & 30 & 97 & 80.8 & \\
\hline \multirow{2}{*}{ Sold on farm } & No & 29 & 24.2 & 12 & 10.0 & 41 & 34.2 & \multirow[t]{2}{*}{$4.065 * * *$} \\
\hline & Yes & 38 & 31.7 & 41 & 34.2 & 79 & 65.8 & \\
\hline
\end{tabular}

Source: Own survey result, 2017 , *** means significant at $1 \%$ probability levels.

Dummy variables: Majority of the respondents were literate, only $32.5 \%$ of them were illiterate. The comparison between female headed and male headed households showed that $4.8 \%$ female headed and $21.7 \%$ male headed have education (according to their opinion). The chi-square test revealed that there was statistically significant mean difference between the two groups in terms of education at less than $1 \%$ probability level (Table 2).

About $79 \%$ of the sample households were sold their milk on farm. The comparison between female headed and male headed households showed that $38 \%$ female headed and $41 \%$ male headed households were sold on farm. The chi-square test revealed that there was statistically significant mean difference between the two groups in terms where to sold milk at less than $1 \%$ probability level (Table 2).

About $50 \%$ of the sample households were provide supplement to their dairy cattle. The comparison between female headed and male headed households showed that $45 \%$ female headed and $15 \%$ male headed households were feed supplement. The chi-square test revealed that there was statistically significant mean difference between the two groups in terms where supplementary feed at less than $1 \%$ probability level (Table 2 ).

The survey results indicated that out of the total respondents, $54.2 \%$ participated in cattle vaccination. From the sample respondents who have participated in cattle vaccination, $35 \%$ and $19.2 \%$ are female headed and male headed households, respectively. The chi-square test for participation in cattle vaccination between the two groups was tested and the differences was found to be significant at $1 \%$ probability level (Table 2 ).

The study result showed that $80.8 \%$ of the sample households get marketing service. When we compare female headed and male headed households $50.8 \%$ of female headed and $30 \%$ of male headed were got marketing service. The-chi square test indicated that there was statistically significant difference between the two groups in terms of access to marketing services at $1 \%$ probability level (Table 2). 
Looking into the estimated coefficients, the results indicate that participation is significantly influenced by five explanatory variables. Education level, extension contact, cultivated land area access to supplementary feeds and access to market information were significant variables which affect the participation of the female headed household in dairy farming.

This variable was positively related and statistically significant with female headed dairy farming participation at $10 \%$ probability level. The odds ratio of 1.18 implies that, other things being constant, the odds ratio in favour of participating in dairy farm increases by a factor of 1.18 as the household head being female. The possible reason was that education improves farmers' awareness on dairy farming and their benefits are more likely to identify cattle problems and be more sensitive for cattle farm productivity. This result is consistency with the findings of (Batool et al., 2012).

Cultivated area was found to be positively related to the probability of being participated at $10 \%$ significant level. The odds ratio of the variable indicated that other things remain constant; the probability of the female headed household being participated would increase by a factor of 2.4 as the households cultivated area increased by one hectare. The land area is the sources of animal feeds, concentrates and supplants which in turn increases women participation of dairy farming (Table 3 ). This result is consistency with the findings of (Batool et al., 2012 and Meena, 2013).

The result also showed a positive and statistically significant relation of market information with probability of participation at less than $5 \%$ probability level. Its odds ratio effect shows that, as women accessed market information, their probability of participation in dairy farming increases by 1.03 , other variables being constant. The implication of this result is that, market information services require the marketing of livestock and their products and therefore farmers increases their dairy farm income (Table 3).

Agricultural extension contact was found to be positively related to the probability of being participated at $1 \%$ significant level. The odds ratio of the variable indicated that other things remain constant; the probability of the female headed being participated would increase by a factor of 1.55 as the household's heads extension contact increase by one unit. Improved animal health services of animal healthy extension could hugely women awareness of dairy benefits and husbandry practices (Table 3 ).

Similarly, existence of supplementary feed was found to be positive and statistically significant at $1 \%$ probability level with women participation in dairy farming. The values of odds ratio also implies that if other factors are held constant, the odds ratio in favour of participating in dairy farming increases by a factor of 1.97 as the supplementary feed accessed (Table 3). This result is similar with the findings of (Sarah Yasmin and Yukio Ikemoto. 2015).

Matching female and male headed households: As indicated in Table 4 the common support region is the area which contains the minimum and maximum propensity scores of treatment and control group households, respectively. It requires deleting of all observations whose propensity scores is smaller than the minimum and larger than the maximum of treatment and control, respectively (Caliendo and Kopeinig, 2005). Accordingly, in this study the common support region would lie between 0.042 and 0.84 . In other words, households whose estimated propensity score was less than 0.042 and larger than 0.84 are not considered for the matching exercise. As a result of this restriction, 10 households ( 7 male headed and 2 female headed households) were discarded.

Table 3 Logistic regression results of gender participation in dairy farming

\begin{tabular}{l|ccccc}
\hline \multicolumn{1}{c|}{ Gender } & Coeff & Odd ratio & S.E & $\mathrm{Z}$ & $\mathrm{p}>\mathrm{Z}$ \\
\hline Family size & -.2206251 & 0.1343734 & 0.8020173 & -1.64 & 0.101 \\
Cow numbers & 0.1406586 & 0.2267563 & 0.8687859 & 0.62 & 0.535 \\
Education & $1.188065^{*}$ & 0.6411332 & 0.3048105 & 1.85 & 0.064 \\
Experiences & -0.02013 & 0.0320455 & 0.9800713 & -0.63 & 0.530 \\
Extension & $1.550659^{* * *}$ & 0.4687384 & 4.714577 & 3.31 & 0.001 \\
Off farm income & 0.0003782 & 0.0002821 & 1.000378 & 1.34 & 0.180 \\
Livestock hold & -0.0533668 & 0.1153615 & 0.9480323 & -0.46 & 0.644 \\
Cultivated & $2.404098^{*}$ & 1.287641 & 0.0903469 & 1.87 & 0.062 \\
Grazing & -2.3977 & 2.703962 & 0.0909268 & -0.89 & 0.375 \\
Fodders & 0.1802444 & 0.5361463 & 1.19751 & 0.34 & 0.737 \\
Supplement & $1.968683 * * *$ & 0.6830977 & 0.1396407 & 2.88 & 0.004 \\
Milk sold & 0.8500073 & 0.6151147 & 2.339664 & 1.38 & 0.167 \\
Market inform & $2.840494 * *$ & 1.279439 & 0.0583968 & 2.22 & 0.026 \\
Vaccination & 0.3744617 & 0.5738156 & 1.454208 & 0.65 & 0.514 \\
Constant & 2.242732 & 1.368226 & & 1.64 & 0.101 \\
\hline
\end{tabular}

Number of obs $=120$, LR chi $^{2}(14)=53.82$, Prob $>$ chi $^{2}=0.0000$, Pseudo R ${ }^{2}=0.3267$, Log likelihood $=-55.451095$

Source: Own survey result, 2017. $* * *$ and $* * *$ mean significant at $10 \%, 5 \%$ and $1 \%$ probability level, respectively

Table 4 Distribution of estimated propensity scores

\begin{tabular}{l|ccccc}
\hline \multicolumn{1}{c|}{ Groups } & Observation & Mean & Std. Dev. & Min & Max \\
\hline Total households & 120 & 0.442 & 0.309 & 0.0005 & 0.980 \\
Treatment households & 67 & 0.272 & 0.242 & 0.0005 & 0.840 \\
Control households & 95 & 0.656 & 0.244 & 0.042 & 0.980 \\
\hline
\end{tabular}

Source: Own calculation result, 2017. 
Table 5 Balancing tests of covariates

\begin{tabular}{|c|c|c|c|c|c|c|c|}
\hline \multirow{2}{*}{ Variables } & \multirow{2}{*}{$\begin{array}{c}\text { Unmatch } \\
\text { Match }\end{array}$} & \multicolumn{2}{|c|}{ Mean } & \multicolumn{2}{|c|}{$\%$ Reduced } & \multicolumn{2}{|c|}{ t-test } \\
\hline & & Treated & Control & Bais & Bais & $\bar{Z}$ & $\mathrm{Z}>|\mathrm{P}|$ \\
\hline \multirow{2}{*}{ Propensity score } & $\mathrm{U}$ & 0.65652 & 0.2717 & 158.0 & & 8.60 & 0.000 \\
\hline & M & 0.55013 & 0.52494 & 10.3 & 93.5 & 0.53 & 0.600 \\
\hline \multirow{2}{*}{ Family size } & $\mathrm{U}$ & 6.6604 & 7.2687 & -27.6 & & -1.50 & 0.135 \\
\hline & M & 6.9211 & 6.8341 & 3.9 & 85.7 & 0.15 & 0.880 \\
\hline \multirow{2}{*}{ Milking cow } & $\mathrm{U}$ & 2.7736 & 3.8358 & -68.4 & & -3.71 & 0.000 \\
\hline & M & 3.1316 & 2.9960 & 8.7 & 87.2 & 0.34 & 0.738 \\
\hline \multirow{2}{*}{ Education } & $\mathrm{U}$ & 0.49057 & 0.82090 & -73.5 & & -4.06 & 0.000 \\
\hline & M & 0.63158 & 0.64370 & -2.7 & 96.3 & -0.11 & 0.914 \\
\hline \multirow{2}{*}{ Experience } & $\mathrm{U}$ & 25.302 & 25.388 & -1.2 & & -0.06 & 0.950 \\
\hline & M & 25.026 & 25.571 & -7.4 & -532.6 & -0.31 & 0.757 \\
\hline \multirow{2}{*}{ Extension } & $\mathrm{U}$ & 2.3962 & 2.7313 & -29.8 & & -1.63 & 0.106 \\
\hline & M & 2.5789 & 2.4860 & 8.3 & 72.3 & 0.31 & 0.758 \\
\hline \multirow{2}{*}{ Off-farm income } & $\mathrm{U}$ & 2506.3 & 2439.5 & 4.7 & & 0.26 & 0.795 \\
\hline & M & 2192.4 & 2028.5 & 11.6 & -145.2 & 0.48 & 0.636 \\
\hline \multirow{2}{*}{ Livestock hold } & $\mathrm{U}$ & 0.84057 & 2.1299 & -20.1 & & -1.03 & 0.304 \\
\hline & M & 0.83684 & 0.83064 & 0.1 & 99.5 & 0.04 & 0.971 \\
\hline \multirow{2}{*}{ Cultivated } & $\mathrm{U}$ & 0.52358 & 0.70149 & -34.3 & & -1.82 & 0.072 \\
\hline & M & 0.51579 & 0.53611 & -3.9 & 88.6 & -0.21 & 0.831 \\
\hline \multirow{2}{*}{ Grazing } & $\mathrm{U}$ & 0.07358 & 0.15000 & -64.5 & & -3.48 & 0.001 \\
\hline & M & 0.07368 & 0.08182 & -6.9 & 89.3 & -0.29 & 0.769 \\
\hline \multirow{2}{*}{ Fodders } & $\mathrm{U}$ & 0.47170 & 0.44776 & 4.8 & & 0.26 & 0.796 \\
\hline & M & 0.50000 & 0.47195 & 5.6 & -17.2 & 0.24 & 0.810 \\
\hline \multirow{2}{*}{ Supplement } & $\mathrm{U}$ & 0.28302 & 0.67164 & -83.7 & & -4.54 & 0.000 \\
\hline & M & 0.36842 & 0.36476 & 0.8 & 99.1 & 0.03 & 0.974 \\
\hline \multirow{2}{*}{ Milk sold } & $\mathrm{U}$ & 0.77358 & 0.56716 & 44.6 & & 2.40 & 0.018 \\
\hline & M & 0.71053 & 0.67871 & 6.9 & 84.6 & 0.30 & 0.767 \\
\hline \multirow{2}{*}{ Market info } & $\mathrm{U}$ & 0.67925 & 0.91045 & -59.2 & & -3.31 & 0.001 \\
\hline & M & 0.84211 & 0.77345 & 17.6 & 70.3 & 0.75 & 0.454 \\
\hline \multirow{2}{*}{ Vaccination } & $\mathrm{U}$ & 0.43396 & 0.62687 & -39.1 & & -2.13 & 0.035 \\
\hline & M & 0.55263 & 0.53642 & 3.3 & 91.6 & 0.14 & 0.889 \\
\hline
\end{tabular}

Source: Own survey result, 2017.

Testing the balance of propensity score and covariates: After choosing the best performing matching algorithm the next step is to check the balancing of propensity score and covariate using different procedures by applying the selected matching algorithm (in our case kernel matching). As indicated earlier, the main purpose of the propensity score estimation is not to obtain a precise prediction of selection into treatment, but rather to balance the distributions of relevant variables in both groups.

The mean standardized bias before and after matching are shown in the fifth columns of Table 5, while column six reports the total bias reduction obtained by the matching procedure. In the present matching models, the standardized difference in covariate before matching is in the range of $1.2 \%$ and $83.9 \%$ in absolute value. After matching, the remaining standardized difference of covariate for almost all covariates lie between $0.1 \%$ and $17.6 \%$, which is below the critical level of $20 \%$ suggested by Rosenbaum and Rubin (1983). In all cases, it is evident that sample differences in the unmatched data significantly exceed those in the samples of matched cases. The process of matching thus creates a high degree of covariate balance between the participant and nonparticipant samples that are ready to use in the estimation procedure. Similarly, t-values in Table 5 shows that before matching almost half of chosen variables exhibited statistically significant differences while after matching all of the covariates are balanced and become statistically significant.

\section{Choice of Matching Algorithm}

The choice of matching estimator is decided based on the balancing qualities of the estimators. According to (Dehejia and Wahba, 2002), the final choice of a matching estimator was guided by different criteria such as equal means test referred to as the balancing test, pseudo- $\mathrm{R}^{2}$ and matched sample size. Balancing test is a test conducted to know whether there is statistically significant difference in mean values of the two groups of the respondents and preferred when there is no significant difference after being matched. Accordingly, matching estimators were evaluated via matching the female headed and male headed households in common support region. Therefore, a matching estimator having balanced or insignificant mean differences in all explanatory variables, bears a low pseudo- $\mathrm{R}^{2}$ value and also the one that results in large matched sample size is preferred. In line with the above indicators of matching quality, kernel matching with 0.25 band widths is resulted in a best fit matching estimator.

The balancing test results of low pseudo- $\mathrm{R}^{2}$ and the insignificant likelihood ratio tests support the hypothesis that both groups have the same distribution in covariates $\mathrm{X}$ after matching (Table 5). These results clearly show that the matching procedure is able to balance the 
characteristics in the female headed and the matched male headed groups. We, therefore, used these results to evaluate the impact of gender on outcome variable among groups of households having similar observed characteristics. This allows comparing observed outcomes for female headed with those of a comparison groups sharing a common support.

Impact Estimates on Households' Food Security Status.

The estimation result provides supportive evidence of statistically significant effects of the gender on farm household's food security status. After controlling for differences in demographic, location and asset endowment characteristics of the female headed and male headed households, it has been found that, on average, female headed household has increasing rate of food security status by $66 \%$ (Table 6,7 ).

\section{Determinants of Dairy Cattle Benefits}

Looking into the estimated coefficients, the results indicate that participation is significantly influenced by five explanatory variables. Extension contact, education level, milk sold on farm, vaccination, fodder, land area and market information were significant variables which affect the dairy benefits. Those variables are explained as follows.

Educational level of household head was found significant at $1 \%$ probability level and positively influence dairy income indicating that relatively more educated farmers recognize the advantages of dairy cattle than less educated. This is because of the fact that education enhances farmers' ability to perceive, interpret, and respond to new livestock technology. It also enables farmers to be more aware of the improved technology. The marginal effect indicated that as education level of household head increased by one year the dairy cattle income increased by 1815 birr (Table 8). This result is consistency with the findings of (Tabby et al, 2015; Meena, 2013).

Size of land has positive influence on the dairy income in the study area. It was significant at $5 \%$. Farmers who have larger farmland would have more cattle income than those with smaller land size. Increase in size of land has positive relationship with the amount of production to be harvested. Therefore, those farmers who have more land becomes in a better position than those who have less. The output of the model shows that land area has positive relationship with dairy cattle income. The coefficient implies that with all other factors kept constant, the cattle income increase by Birr 228 with increase in size of land by one hectare (Table 8). This result is in conformity with the finding of (Nenghanjawa, 2005).
Fodder supplement is statistically significant at $1 \%$ probability level. The positive relationship indicates that households that supplement fodder to their dairy cattle may have the opportunity to increase milk and other cattle products. The coefficient of the variable shows that as the household being supplement the fodder to their cattle the income increases by Birr 917 and this may lead to improved income from household cattle production (Table 8 ). This result is in conformity with the finding of (Tefera, 2014).

Age of household head was positively related and statistically significant with probability of participation at $10 \%$ probability level. The odds ratio of 1.05 implies that, other things being constant, the odds ratio in favour of using vaccination increases by a factor of 1.05 as age increase by one year. The possible reason was that older farmers are more likely to identify cattle problems and be more sensitive for cattle productivity (Table 8). This result is consistency with the findings of (Tabby et al, 2015).

Vaccination has a positive sign as expected and significant at less than $1 \%$ probability level. This implies that, other things being constant, households' access to vaccination increases cattle income by birr 1058. This is due the advantage of vaccination in protecting animal disease and in turn which improves cattle production and productivity (Table 8). This result is in conformity with the finding of (Nenghanjawa, 2005).

Milk sold on farm: result also showed a negative and statistically significant relation with dairy income at $1 \%$ probability level. This shows that, one-unit increase in milk produced on farm decreases cattle income by 1364 Ethiopian birr, other variables being constant. The implication of this result is that, most of the cattle output was not sold on cash if it's on farm and some of it taken as a gift rather than sold (Table 8). This result is similar with the findings of (Kelay et al, 2002).

Market information has been found to be positively related to cattle income at $5 \%$ significant level. This indicated that other things remain constant; market information access of the household would increase cattle income by birr 1426.9. Improved market information could hugely increase livestock productivity and the earnings of their owners (Table 8). This result is in conformity with the finding of (Nenghanjawa, 2005).

Extension contact has been found to be positively related to dairy cattle benefit at $5 \%$ significant level. This indicated that other things remain constant; cattle income increase by birr 556.5 as the household's extension contact increase by one unit. Improved animal health services provided by extension could hugely increase livestock productivity and the earnings of their owners (Table 8). This result is consistency with the findings of (Tabby et al, 2015; Meena, 2013).

Table 6 Chi-square test for the joint significance of variables

\begin{tabular}{l|ccc}
\hline \multicolumn{1}{c|}{ Sample } & Ps R $^{2}$ & LR chi $^{2}$ & p>chi2 \\
\hline Unmatched & 0.329 & 54.140 & 0.000 \\
Matched & 0.046 & 4.790 & 0.994 \\
\hline
\end{tabular}

Source: Own survey result, 2017.

Table 7 Average Treatment Effects on the treated (ATT)

\begin{tabular}{|c|c|c|c|c|c|c|}
\hline Variable & Sample & Treated & Controls & Difference & S.E. & T-stat \\
\hline Food security & ATT & 0.263157895 & 0.88978698 & -0.62662908 & 0.096314856 & $-6.51 * * *$ \\
\hline
\end{tabular}


Table 8 Determinants of dairy cattle benefits (dairy income)

\begin{tabular}{l|cccc}
\hline \multicolumn{1}{c}{ Variables } & Coefficient & Std.err & $\mathrm{T}$ & $\mathrm{p}>\mathrm{t}$ \\
\hline Gender & -59.692 & 363.684 & -0.160 & 0.870 \\
Family size & -12.166 & 79.484 & -0.150 & 0.879 \\
Education & $1815.505^{* * *}$ & 404.954 & 4.480 & 0.000 \\
Experience & 14.079 & 19.843 & 0.710 & 0.480 \\
Land area & $228.264 * *$ & 101.711 & 2.240 & 0.027 \\
Cultivated area & 119.483 & 343.989 & 0.350 & 0.729 \\
Grazing area & 1880.854 & 1420.459 & 1.320 & 0.188 \\
Fodders & $917.228 * * *$ & 316.421 & 2.900 & 0.005 \\
Supplements & 170.782 & 376.029 & 0.450 & 0.651 \\
On farm sold & $-1364.596 * * *$ & 334.997 & -4.070 & 0.000 \\
Mkt information & $1426.942 * *$ & 631.058 & 2.260 & 0.026 \\
Of farm income & -.1244312 & .137319 & -0.910 & 0.367 \\
Vaccination & $1058.303 * * *$ & 337.281 & 3.140 & 0.002 \\
Extension & $-556.542 * *$ & 237.005 & -2.350 & 0.021 \\
Constant & 1445.379 & 919.050 & 1.570 & 0.119 \\
Number of obs $=120$, R-squared $=0.6513, \mathrm{~F}(14,105)=14.010$, Adj R-squared $=0.6048$, Prob $>\mathrm{F}=0.0000$
\end{tabular}

Source: Own computation. 2017, ** and *** mean significant at $5 \%$ and $1 \%$ probability level, respectively

\section{Conclusion}

The present study suggests that, in order to maximize the dairy farm productivity a strong extension program needs to be implemented to transfer adoptable technologies and women education and market information access to enhance the knowledge and skills of women in all aspects of livestock management practices including husbandry, calf rearing, health and value addition to milk through improving female headed dairy farming participation.

Dairy farming is important development effort to ensure agricultural productivity if properly implemented. In Ethiopia female headed and male headed households are participated in dairy farming. However, this study has found evidence that female headed households in the study area has benefited from their dairy cattle than male headed households. Accordingly, the estimation result indicated that there are significant differences in farm households' food security status between female headed and male headed households particularly and or in the households' welfare generally, which could be attributable to the household level female headed dairy farming participation. Dairy cattle farming should be promoted to women. This has an encouraging message for program designers, implementers, and funding agents to take proper action to achieve the intended goals of household's securing food security by improving cattle production and productivity. Based on the empirical findings reported in this paper, the following recommendations are forwarded:

Education of the household head has a positive and significant effect on dairy cattle benefits. This is due to the fact that education enhances the smallholder farmers' knowledge and skills that used in dairy cattle management, feeding and protecting against animal diseases. So development agents and elder members should have increase smallholder farmer's education and skill improvement training to enhance dairy cattle benefits. Vaccination is also positively related to dairy cattle benefits. Those households that are situated participate in cattle vaccination obtained more benefits than non-participated. Therefore, the construction of animal health and cattle vaccination center should have accessed to villages for a better use of the vaccination by households.

Extension contact and education level are positively and significantly related indicating improves household dairy benefits. Therefore, household must be trained as to how to increase production per unit area and the economic and social benefits of dairy farming should be conducted and enable the farmers to diversify their cattle production and income sources. Market information is also positively related to dairy cattle benefits. Therefore, government and other stakeholders should increase information communication technologies to improve dairy cattle benefits. Fodder supplement is another variable that influence dairy cattle benefits. Small scale dairy cattle producers should be cultivated different animal forage on the corner side of their farm land to enhance their dairy benefits.

\section{References}

Alary V, Corniaux C, Gautier D. 2011. Livestock's contribution to poverty alleviation: how to measure it? World Development, 39(9), 1638-1648. http://doi.org/10.1016/j.worlddev.2011.02.008.

Ayele S, Assegid W, Jabbar MA, Ahmed M, Belachew H. 2003. Livestock marketing in Ethiopia: A review of structure, performance and development initiatives. Socio-economic and Policy Research Working Paper 52. International Livestock Research Institute, Nairobi, Kenya. Available from: https://www.researchgate.net/publication/264457494. Accessed 15.9.2017.

Behnke R, Meta F. 2011. The contribution of livestock to the Ethiopian economy-part II. IGAD LPI (Livestock Policy Initiative of the Intergovernmental Authority on Development) Working Paper 02-11. Addis Ababa, Ethiopia. Available from http://citeseerx.ist.psu.edu/viewdoc/download? doi=10.1.1.366.963\&rep=rep1\&type=pdf. Accessed 12.10.2017. 
Becker SO, Caliendo M. 2007. Sensitivity analysis for average treatment effects. Stata Journal, 7(1): 71-83. Available from: https://econpapers. repec.org/RePEc :tsj:stataj:v:7:y:2007:i:1:p:71-83. Accused 02.9.2017.

Betty N. 2005. Gender relation in livestock production and ownership: implications for household food security in the Teso farming system. MScthesis,78 pp. Makerere University, Uganda. Available from: https://assets.publishing.service.gov.uk/media/57a08c20e52 74a31e0000ff0/R8108e.pdf Accessed 9.10.201.

Batool Z, Warriach HM, Ishaq M, Latif S, Rashid MA, Bhatti A, Murtaza N, Arif S, Wynn PC. 2012. Participation of women in dairy farm practices under small holder production system in Pakistan. University of Veterinary and Animal Sciences, Lahore, Pakistan, EH Graham Center for Agricultural Innovation, Charles Sturt University, Australia. Proceedings of the $15^{\text {th }}$ AAAP Animal Science Congress 26-30 November 2012, Thammasat University, Rangsit Campus, Thailand

Carletto C, Zezza A, Banarjee R. 2012. Towards better measurements of household food security: harmonizing indicators and the role of household surveys. Global Food Security 2(1),30-40. http://dx.doi.org/10.1016/j.gfs.2012 .11 .006

CSA. 2010. Livestock and livestock characteristics. Agricultural sample survey. Central Statistical Agency, Statistical Bulletin 578. Available from: http://www.csa.gov.et/ ehioinfo-internal.html?download=723:livestock-andlivestock-characteristics-survey-report-for-the-year-2007-ec-2014-2015\&start=10.Accessed15.10.2017.

CSA. 2013. Report on efficiency of cattle and buffalo in and around Darbhanga, livestock and livestock characteristics. Central Statistical Agency, Agricultural sample survey. Available from: http:// www.csa.gov.et/list-activities/ naming-and-coding/category/174-eth-ag.pdf. Accused 10.10.2017

CSA 2015. Annual population growth estimation. Statistical Abstract of Ethiopia, Central Statistical Agency, Addis Ababa, Ethiopia. Available from: http://microdata. worldbank.org/ index.php/ catalog/2783/ download/ 39570 pdf. Accused 10.9.2017.

Caliendo, M, Kopeinig S, 2005. Some practical guidance for the implementation of propensity score matching, Discussion Paper No. 1588, University of Cologne. Available from: http:// ftp.iza.org/ dp1588.pdf. Accused 18.9.2017.

Cecchi G, Wint W, Shaw A, Marletta A, Mattioli R, Robinson T. 2010. Geographic distribution and environmental characterization of livestock production systems in Eastern Africa. Agriculture, Ecosystems \& Environment 135(1-2), 98-110. https://doi.org/10.1016/j.agee.2009.08.011

Dehejia RH, Wahba S. 2002. Propensity score matching methods for non- experimental causal studies. The Review of Economics and Statistics, 84(1): 151-161.Available from: http://www.nber.org/ papers/ w6829.Accesed 12.10.2017.

DE Weerdt J, Beegle, K, Friedman J, Gibson J. 2014. The challenge of measuring hunger. Policy Research Paper 6736. World Bank Publications, Available from: http://documents. World bank.org/curated/en/566471468313233524/pdf/ WPS6736.pdf.Accessed 02.11.2017.

Dejene A. 2003. Integrated natural resource management to enhance food security: the case for community-based approaches in Ethiopia. Working Paper, No 16. Food and Agriculture Organization of the United Nations, Rome, Italy. Ministry of Agriculture, Addis Ababa, Ethiopia. Available from: http://www.fao.org/tempref/docrep/fao/005/ Y4818E/Y4818E00.pdf Accessed 4.8. 2017.

FAO. 2010. Roles of women in agriculture. Food and Agriculture Organization of the United Nations, Available from: http://www.fao.org/docrep/013/am307e/am307e00. pdf.Accessed 5.9.2017.
FAO. 2011. The State of Food and Agriculture (SOFA) 20102011-Women in agriculture: Closing the gender gap for development. Food and Agriculture Organization of the United Nations, Available from: http://www.fao. org/docrep/013/i2050e/i2050e00.htm.Accessed 10.10.2017.

FAO. 2012. Livestock sector development for poverty reduction: an economic and policy perspective - Livestock's many virtues. Food and Agriculture Organization of the United Nations, Available from: http://www.fao.org/docrep/ 015/i2744e/i2744e00.pdf.Accessed 8.11.2017.

FAOSTAT.2009. Online database on agriculture. Food and Agricultural Organization of the United Nations Statistics, Available from: http://www.faostat.fao.org. Accessed 7.9.2017.

FAOSTAT. 2013. Online database on agriculture. Food and Agricultural Organization of the United Nations Statistics. Available from: http://faostat3.fao.org/faostat gateway/ go/to/ compare/Q/QC/E. Accessed 20.10.2017.

Fekadu D. 2009. Characterizing farming practices from three regions of Ethiopia on which Enset (Ensete ventricosum) is widely profited as a multipurpose crop plant. Livestock Research for Rural Development 21 (12). Available from: http://www.lrrd.org/lrrd21/12/ feka21213.htm. Accused 02.12.2017.

IFAD. 1999. Livestock Memory check. The International Fund for Agricultural Development, Available from: http://www.ifad.org/pub/memory/e/insert2.pdf. Accessed 5.10.2017.

ILRI .2007. Markets that works - Making a living from livestock. International Livestock Research Institute, Kenya. Available from: http://mahider.ilri.org/bitstream /handle/10568/567/. Accussed 01.12.2017.

Hoddinott J. 2001. Methods for Rural Development Projects. Choosing Outcome Indicators of Household Food Security. IFPRI, Washington, D.C. pp. 31-73.

Jones AD, Ngure FM, Pelto G, Young SL. 2013. What are we assessing when we measure food security? A compendium and review of current metrics. Advances in Nutrition An International Review. Journal 4, 481-505. http://doi:10.3945/an.113.004119

Karanja-Lumumba T, Mugambi J,Wesonga F. 2015. Adoption of East Coast fever vaccine among smallholder dairy farmers in Kenya: The Case of North Rift Kenya. Kenya Agricultural and Livestock Research Organization, Veterinary Science Research Institute, East African Agricultural and Forestry Journal, 2015 81( 1), 34-39.

Kelay B, Jürgen M, Nagel U,Herzog H. 2002. Analyses of dairy cattle breeding practices in selected areas of Ethiopia. $\mathrm{PhD}$ Thesis, 175 pp. Humboldt-university Berlin. Available from: https:// www. researchgate.net/publication/33784632. Accessed 9.10.2017

Mekonnen A, Haile A, Dessie T, Mekasha Y. 2012. On farm characterization of Horro cattle breed production systems in western Oromia, Ethiopia. Livestock Research for Rural Development, 24(6). Available from:http://www.lrrd.org/ lrrd24/6/meko24100.htm accessed 10.11.2017.

Meena HR. 2013. Livestock farmers' participation and factors affecting the success of animal health care program in Hill Region. Journal of Human Ecology, 41(3): 255-261. https://doi.org/10. 1080/ 09709274 .2013.11906573

Mendola M. 2007. Agricultural technology adoption and poverty reduction: A propensity-score matching analysis for rural Bangladesh. Journal of Food Policy, 32: 372-393. Available from; https://ispc. cgiar.org/sites/default/files/ pdf/97.pdf. Accused 28.8.2017

MOFED. 2012.The Federal Democratic Republic of Ethiopia, Growth and Transformation Plan (GTP) 2010/11-2014/15, Draft. Trends and prospects for meeting MDGs by 2015, millennium development goal report. Addis Ababa, Ethiopia. Available from: http://documents. worldbank. org/curated/en/561281468031489534/pdf/718. Accused 4.9.2017. 
Nigatu R, Ansha Y. 2009.Gender differentials in migration impacts in Southern Ethiopia. Journal of the Anthropologist, 11(2) 219-237. Available from: https://doi.org/ 10.1080/ 09720073.2009. 11891092. Accused 10.12.2017.

Okali C, Sumberg J. 1985. Sheep and goats, men and women Household relations and small ruminant development in southwest Nigeria. Available from: http://pdf.usaid.gov/pdf_docs/PNAAT009.pdf Accessed 2511.2017.

Rosembaum PR, Rubin DB. 1983. The central role of the propensity score in observational studies for causal effects. Biometrika, 70(1): 41-55. available from: http://www.stat.cmu.edu/ ryantibs/ journal club/ rosenbaum_1983.pdf. Accused 10.11.2017.

Tallam EJ. 2009. Influence of gender access to and control over resources on milk production among smallholder dairy farmers in Kabarnet division, Baringo district. Msc Thesis, 93 pp., Egerton University, Available from: http://hdl.handle.net/123456789/201.Accessed 5.11.2017.
Tefera T, Tefera F. 2014. Determinants of households' food security and coping strategies for food shortfall in Mareko District, Guraghe Zone Southern Ethiopia. Journal of Food Security, 2(3): 92-99. http://doi:10.12691/jfs-2-3-4.

WHO. 2009. Neglected tropical diseases, hidden successes, emerging opportunities. World Health Organization, Available from: http://whqlibdoc.who.int/ publications/2009/ 9789241598705 _eng. pdf. Accessed 6.9.2017.

Yasmin S. Ikemoto Y. 2015. Women's participation in smallscale dairy farming for poverty reduction in Bangladesh. American International Journal of Social Science Vol. 4, No. 5; 21-33. Available from: http://www.aijssnet.com/ journals/Vol_4_No_5_October_2015/3.pdf.Accessed 25.9.2017. 